\title{
群馬県のナラ枯れを起こしたカシノナガキクイムシは在来か近年移入の個体群か 一遺伝解析に基づく検証一
}

\author{
岡 崎 千 聖 1 逢沢峰昭 ${ }^{* 1}$ ・森嶋佳 織 ${ }^{2} \cdot$ 福 沢 朋 子 ${ }^{2} \cdot$ 大久保達弘 ${ }^{1}$
}

\begin{abstract}
群馬県では県北部のみなかみ町に押いて 2010 年に初めてナラ枯れが発生した。このような飛び地的被害を起こしたカシノナ ガキクイムシ個体群の由来について, 隣接県から近年自然または人為的に移入した, 遠方から人為的に移入した, 在来由来の 三つの仮説が考えられた。もし，移入個体群であれば遺伝的多様性の低下や遺伝的に遠い系統がみられると予想される。本研 究ではこれらの仮説を遺伝解析に基づいて検証した。みなかみ町およびナラ枯れの起きている近隣 6 県において, カシノナガ キクイムシ試料を採集し，核リボソーム DNA，ミトコンドリアDNA およよ゙゙核マイクロサテライト（SSR）を用いて遺伝解析 を行った。核りボソーム DNA および核 SSR の遺伝構造解析の結果, 群馬個体群は福島や新潟と同じ日本海型の北東日本タイ プに属したことから，南西日本から人為的に移入したものではないと考えられた。また，ミトコンドリアDNAと核 SSRを用 いて各個体群の遺伝的多様性を調べた結果，群馬個体群の遺伝的多様性は低くはなく，他個体群と違いはなかった。よって， 群馬個体群は近年の移入由来ではなく, 在来由来と考えられた。

キーワード：遺伝的多様性，遺伝構造，ミトコンドリア DNA，核マイクロサテライト，28S リボソーム DNA
\end{abstract}

\begin{abstract}
Chisato Okazaki, ${ }^{1}$ Mineaki Aizawa, ${ }^{*, 1}$ Kaori Morishima, ${ }^{2}$ Tomoko Fukuzawa, ${ }^{2}$ Tatsuhiro Ohkubo ${ }^{1}$ (2018) Indigenous or Recently Migrated Population?: The Origin of Platypus quercivorus Population Causing Japanese Oak Wilt in Gunma Prefecture, Inferred from Genetic Analyses. J Jpn For Soc 100: 116-123 Mass mortality of oak by Japanese oak wilt disease is caused by an ambrosia beetle vector, Platypus quercivorus. In northern Gunma Prefecture, a geographically isolated mass mortality occurred in Minakami in 2010 for the first time. We hypothesized three origins of the beetle population causing the isolated mass mortality: (1) a population recently migrated naturally or artificially from near or neighboring prefectures, which might exhibit a low genetic diversity due to founder effect; (2) a recently artificially migrated population from a distant area, which might have genetically different lineages and a low genetic diversity due to founder effect; and (3) an indigenous population, which exhibits a relatively high genetic diversity. We examined these hypotheses using variations of nuclear ribosomal DNA (rDNA), mitochondrial DNA (mtDNA), and nuclear microsatellite (nSSR) for Gunma and six other neighboring or nearby prefecture populations. Genetic structures of rDNA and nSSR showed that the Gunma population belonged to a northeastern Japanese Sea of Japan-side lineage, as had neighboring prefecture populations, indicating that the Gunma population did not recently migrate from a distant area with different lineages through human activity. Genetic diversity of mtDNA and nSSR indicated that the Gunma population exhibited a moderate genetic diversity, similar to the other populations. Therefore, we concluded that the Gunma population might have originated from an indigenous population.
\end{abstract}

Key words: genetic diversity, genetic structure, mitochondrial DNA, nuclear microsatellite, 28S rDNA

\section{I. は じめ に}

カシノナガキクイムシ Platypus quercivorus (以下, カシ ナガと呼ぶ）の穿入に伴う，樹幹内への病原菌 Raffaelea quercivora の伝播によって発生するナラ類の集団枯損被害 （以下，ナラ枯れと呼ぶ）が，1980年代から日本海側を中 心に増加し, 内陸部や太平洋側にも拡大し, 被害面積は年々 増加した（伊藤・山田 1998）。現在, 全国的なナラ枯れの 被害量自体は減少しているものの, 新たに発生した地域や 被害量が増加している地域もみられる（林野庁 2015）。

ナラ枯れ被害の拡大速度は主に $2 \mathrm{~km} /$ 年とされるが（布 川 1993; 小林・荻田 2000), その具体的な仕組みはまだはっ きりしない。被害地から十数 $\mathrm{km}$ も離れた無被害地で飛び 地的に被害が発生することもあり（小林・上田 2001 ; 布 川 2001 ; 佐藤ら 2004), その原因としていくつかの仮説 が考えられている。例えば，カシナガが風に乗って大量移 動し, その年にナラ枯れ被害を引き起こしたという仮説で
ある（在原ら 2008）。あるいは, 風に乗って少数のカシナ ガが移動し，その年はナラ枯れを引き起こすことなくナラ 類に穿入する。そして, 次年度以降に急激にカシナガの個 体数密度が上昇し, ナラ枯れを引き起こしたという仮説で ある（在原ら 2008）。一方, 無被害地に低密度で生息して いた在来のカシナガの個体数密度が, 何らかの理由によっ て急激に上昇し, ナラ枯れを引き起こしたという仮説（小 林・野崎 2009）も考えられている。前 2 者の仮説ではナ ラ枯れ被害拡大においてはカシナガの長距離移動の影響が 大きいと考えられている。ここでカシナガの飛翔行動は繁 殖期の 6 月上旬〜 10 月下旬と比較的長期にわたる。しかし, 寄主木を脱出した後, 約 $70 \%$ の成虫が飛翔開始 2 週間で 新たな寄主木へ穿孔する（在原ら 2008）。このため, 個々 の成虫の飛翔期間は短いことが予想される。さらに, キク イムシ科甲虫は寄主木の探査に視覚もしくは嗅覚を用いる (Bernays and Chapman 1994）とされ，また，林分単位にお ける被害木の推移は前年の被害木周辺に集中するという報

\footnotetext{
*連絡先著者（Corresponding author） E-mail: aizawam@cc.utsunomiya-u.ac.jp

1 宇都宮大学農学部森林科学科 ₹321-8505 栃木県宇都宮市峰町 350 (Department of Forest Science, Faculty of Agriculture, Utsunomiya University, 350 Mine-machi, Utsunomiya, Tochigi 321-8505, Japan)

2 東京農工大学大学院連合農学研究科環境資源共生科学専攻 ₹321-8505 杤木県宇都宮市峰町 350 (Department of Symbiotic Science of Environment and Natural Resources, United Graduate School of Agricultural Science, Tokyo University of Agriculture and Technology, 350, Mine-machi, Utsunomiya, Tochigi 321-8505, Japan)

(2018 年 3 月 21 日受付 : 2018 年 6 月 16 日受理)
} 
告もある（小林・上田 2005）。したがって, カシナガは実 際にはそれほど大きな長距離移動はしないか, あるとして も稀であろう。

群馬県では 2010 年に県北部に位置する利根郡みなかみ町 湯檜曾で初めてナラ枯れ被害が報告され (浅野 2011), 現 在も県内ではみなかみ町でのみ被害が継続している。上述 のカシナガの移動に関する先行研究を考慮すると, 群馬県 へのカシナガの由来について三つの仮説が考えられる。一 つ目は新潟県などの近隣県から, 近年, カシナガが群馬県に 自然移入あるいは人為的に移入したという仮説である。みな かみ町に隣接する新潟県南魚沼郡湯沢町などでは 2004 年か ら大きなナラ枯れ被害が発生している（布川 2007）。新潟・ 群馬県境には標高 $1,500 \mathrm{~m}$ 以上の谷川連峰が存在するもの の, 群馬県の被害地と最も近い新潟県湯沢町の被害地は直 線距離にして約 $10 \mathrm{~km}$ である。加えてナガキクイムシ科の Platypus apicalis の最大飛行距離が $2 \mathrm{~km}$ (Milligan 1982) で あることや, 群馬県での被害の初発生年（2010）の南魚沼 郡湯沢町からみなかみ町への卓越風はみなかみ町方面に向 かう北西の風向であったことから (福沢 未発表), 新潟県 のカシナガが段階的あるいは機会的に群馬県へ自然移入し た可能性が考えられる。また, 林野庁 (2015) はナラ枯れ 被害地域からシイタケのほだ木などで被害木が移動するこ とで未被害地において被害が発生する可能性を指摘してい る。したがって, 新潟県などの近隣県からの近年の人為的 移入に由来する可能性も考えられる。二つ目は同じくほだ木 などを介してカシナガが南西日本などの遠方から近年人為 的に移入したという仮説である。三つ目は, 在来個体群に由 来するという仮説であり，上の二つの仮説が支持されなかっ た場合，この仮説が考えられる。

これらの仮説の検証には, 遺伝解析が有効と考えられる。 一般的に移入や分布拡大などで生じた少数個体を起源とす る個体群の遺伝的組成の変化は創始者効果 (founder effect）と呼ばれ, 創始者効果は遺伝的多様性の減少をもた らす (Frankham et al. 2002)。したがって, もし, 近隣県の 個体群から少数の個体が群馬県に移入し, それを元に個体 群が拡大したのであれば, 群馬個体群の遺伝的多様性は低 くなると予想される。反対に, 群馬県の遺伝的多様性が他
個体群と比較して低くない場合は, 群馬県に在来した個体 群に由来することが示唆される。また, 日本のカシナガは 核のリボソーム DNAを用いた遺伝解析により日本海型と 太平洋型に分かれる（Hamaguchi and Goto 2010）。さらに, 核のマイクロサテライト（SSR）マーカーを用いた遺伝解 析により, 日本海型の系統は糸魚川静岡構造線より北東に みられるタイプと南西に拡がるタイプに分かれることが示 されている (Shoda-Kagaya et al. 2010)。これらの先行研究 では群馬県のカシナガ個体群は解析されていないが, これ ら DNAの地理的遺伝構造を調べることで, 群馬県のカシ ナガ個体群が糸魚川静岡構造線より南から人為的に移入し たかどうか検証できると考えられる。また, カシナガに対 してミトコンドリア DNA を用いた報告はないが, 例えば, スギカミキリ Semanotus japonicus ではミトコンドリア DNA の地理的な違いが認められている（Shoda et al. 2003）。し たがって, カシナガのミトコンドリア DNA を調べることで, 群馬県のカシナガ個体群の由来に関する情報が得られる可 能性がある。

本研究では群馬県のカシナガ個体群の由来に関する三つ の仮説, すなわち（1）近年, 近隣県から自然移入あるいは 人為的に移入した，(2) 近年, 南西日本などの遠い系統の カシナガが人為的に移入した，（3）在来個体群由来である, について，核リボソーム DNA，ミトコンドリアDNA，核 SSR のそれぞれを対象とした遺伝解析を基に検証すること を目的とした。

\section{II. 調査地および調査方法}

\section{1. 試料採集}

群馬県においてはみなかみ町（土合および湯原）のカシ ナガ試料を用いた（表-1）。また, 日本におけるカシナガ被 害の報告（林野庁 2017）を基に, 近年, ナラ枯れが発生 しており, かつ群馬県みなかみ町へのカシナガの移入の可 能性のある隣接 3 県 (新潟県, 福島県, 長野県) およびこ れら 3 県に隣接する 3 県 (山形県, 静岡県, 岐阜県) の合 計 6 県のカシナガ個体群の試料を用いた（表-1）。試料採 集にはペットボトル製トラップ, 自作の吊り下げ式簡易型 屋根付き Flight Interception Trap（渡辺 2009）, 透明および

表-1. 遺伝解析に供したカシノナガキクイムシ試料

Information on Platypus quercivorus samples used for genetic analyses.

\begin{tabular}{|c|c|c|c|c|c|c|c|c|c|}
\hline \multirow{2}{*}{ Locality } & \multirow{2}{*}{$\begin{array}{l}\text { Population } \\
\text { Code }\end{array}$} & \multirow{2}{*}{$\begin{array}{l}\text { Latitude } \\
(\mathrm{N})\end{array}$} & \multirow{2}{*}{$\begin{array}{l}\text { Longitude } \\
\text { (E) }\end{array}$} & \multirow{2}{*}{ Alt. (m) } & \multicolumn{3}{|c|}{$\mathrm{N}$} & \multirow{2}{*}{$\begin{array}{c}\text { Collection } \\
\text { method }^{\dagger}\end{array}$} & \multirow{2}{*}{$\begin{array}{c}\text { Year } \\
\text { collected }\end{array}$} \\
\hline & & & & & rDNA & mtDNA & nSSR & & \\
\hline Nishikawa, Yamagata Pref. & YA & $38^{\circ} 25^{\prime} 06.70^{\prime \prime}$ & $140^{\circ} 05^{\prime} 40.20^{\prime \prime}$ & 532 & 9 & 14 & 21 & ST & 2017 \\
\hline Tadami, Fukushima Pref. & FU & $37^{\circ} 20^{\prime} 05.46^{\prime \prime}$ & $139^{\circ} 18^{\prime} 38.85^{\prime \prime}$ & 475 & 8 & 11 & 13 & FIT/FUT & 2017 \\
\hline Yuzawa, Niigata Pref. & NI & $36^{\circ} 53^{\prime} 10.36^{\prime \prime}$ & $138^{\circ} 51^{\prime} 52.61^{\prime \prime}$ & $600-900$ & 10 & 17 & 32 & FIT & 2016 \\
\hline Minakami, Gunma Pref. & GU & $\begin{array}{l}36^{\circ} 49^{\prime} 50.78^{\prime \prime \prime} \\
36^{\circ} 45^{\prime} 51.48^{\prime \prime}\end{array}$ & $\begin{array}{l}138^{\circ} 57^{\prime} 11.58^{\prime \prime} / \\
138^{\circ} 57^{\prime} 47.17^{\prime \prime}\end{array}$ & $735 / 564$ & 8 & 16 & 24 & FUT & 2016 \\
\hline Otari, Nagano Pref. & NA & $\begin{array}{l}36^{\circ} 49^{\prime 2} 23.07^{\prime \prime /} \\
36^{\circ} 45^{\prime} 44.34^{\prime \prime}\end{array}$ & $\begin{array}{l}137^{\circ} 55^{\prime} 05.68^{\prime \prime} / \\
137^{\circ} 54^{\prime 2} 25.58^{\prime \prime}\end{array}$ & $584 / 686$ & 8 & 16 & 21 & ST/FUT & 2017 \\
\hline Hida, Gifu Pref. & GI & $36^{\circ} 25^{\prime} 26.16^{\prime \prime}$ & $137^{\circ} 21^{\prime} 04.80^{\prime \prime}$ & 782 & $0^{*}$ & 2 & 10 & $\log$ & 2014 \\
\hline Shizuoka, Shizuoka Pref. & SH & $34^{\circ} 57^{\prime} 34.73^{\prime \prime}$ & $138^{\circ} 27^{\prime} 13.62^{\prime \prime}$ & 62 & 9 & 16 & 24 & TWT & 2017 \\
\hline Total & & & & & 52 & 92 & 145 & & \\
\hline
\end{tabular}

*Unsuccessfully amplified; ${ }^{\dagger} \mathrm{ST}$, trap with cross barriers and a water basin with propylene glycol; FUT, funnel trap; FIT, self-made flight interception trap with water cups with propylene glycol based on the method of Watanabe (2009); Log, newly emerged adults from logs were collected; TWT, trunk window trap. 
黒色衝突板トラップ (株式会社サンケイ化学), ファンネル トラップ，Trunk Window Trap および被害丸太からの羽化卜 ラップを用いた（表-1）。ペットボトル製トラップ，飛翔ト ラップ，黑色衝突板トラップおよびファンネルトラップの 誘引剤にはカシナガコール L （株式会社サンケイ化学）を 使用した。また，ミトコンドリア DNAの系統解析の外群 として用いるため福島県でルイスナガキクイムシ Platypus lewisi 2 頭採集した。採集試料の同定は, Nobuchi (1973) を基に腹部の突起の形状，胸節のマイカンギアの有無と形 態から行った。その後, $99.5 \%$ エタノールの入った $1.5 \mathrm{~mL}$ チューブに入れ，DNA 抽出まで冷蔵庫 $\left(4^{\circ} \mathrm{C}\right)$ で保存した。

\section{2. 遺伝解析}

実体鏡下でマイクロ剪刀を用いてカシナガの胸節を切り 出し, DNeasy Blood \& Tissue Kit（Qiagen）を用いて全 DNA を抽出した。抽出プロトコルは, 上記キットのマニュアル に従った。抽出したDNAの濃度は NanoDrop One（サーモ フィッシャーサイエンティフィック）を用いて測定し， TE バッファーを用いて $10 \mathrm{ng} / \mu \mathrm{L}$ に希釈・調整した。

まずカシナガの遺伝構造を調べるため, リボソーム DNA とミトコンドリア DNA の部分領域の塩基配列を決定した。 PCR 増幅の悪かった岐阜個体群を除いて，リボソーム DNA の $28 \mathrm{~S}$ 領域については各個体群 8～10 個体，ミトコンドリ ア DNA の COI 部分領域については各個体群 11〜17 個体を 解析に供した（表-1）。リボソーム DNAについては, 28S01 (Forward) と 28SR-inter2（Reverse), 28S-inter1（Forward） と 28SR-01 (Reverse) の 2 組のプライマー $($ Kim et al. 2000 ; Hamaguchi and Goto 2010）を用いて PCR を行っ た。ミトコンドリア DNA については, 動物の DNA バーコー ディングに用いられているプライマー (Herbert et al. 2003) の LCO1490（Forward）と HCO 2198（Reverse）を用いた。 $\mathrm{PCR}$ 反応液は全量が $15 \mu \mathrm{L}$ となるように試薬調整した。内 訳は $10 \mathrm{ng}$ 鋳型 DNA, $1 \times \mathrm{PCR}$ バッファー, $0.2 \mathrm{mM}$ の各 dNTP, $1.5 \mathrm{mM}$ の $\mathrm{MgCl}_{2}, \quad 0.5 \mu \mathrm{M}$ の Forward および Reverse の各プライマー, 0.5 U Taq polymerase（Promega）である。

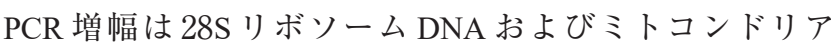
DNA について，それぞれ以下の条件で行った。リボソーム DNA では予熱を $94^{\circ} \mathrm{C}$ で 3 分間行った。その後, 1 サイク ルにつき熱変性を $94^{\circ} \mathrm{C}$ で 1 分，アニーリングを $60^{\circ} \mathrm{C} て ゙ ~ 1$ 分, 伸長を $72^{\circ} \mathrm{C}$ で 1 分 30 秒とし, それを 35 サイクル行っ た。サイクル終了後の伸長は $72^{\circ} \mathrm{C} て ゙ 5$ 分とした。ミトコン

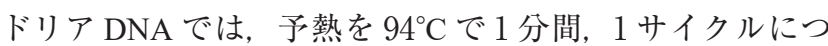
き熱変性を $94^{\circ} \mathrm{C}$ で 45 秒，アニーリングを $50^{\circ} \mathrm{C}$ で 45 秒, 伸長を $72^{\circ} \mathrm{C}$ で 1 分とし, それを 35 サイクル行った。サイ クル終了後の伸長は $72^{\circ} \mathrm{C}$ で 10 分とした。PCR 増幅には, GeneAmp PCR system 2720（Applied Biosystems）を用いた。 得られた PCR 産物を $2 \%$ アガロースゲルで泳動し，目的領 域のみ DNA 増幅がみられた PCR 産物について ExoSAP-IT (Affymetrix) を用いて精製を行った。その後，ABI PRISM BigDye Terminator version 3.1 Cycle Sequencing Kit (Applied Boisystems）と, 28S リボソーム DNA については, 28SR-01 のプライマー以外の 3 本のプライマー, ミトコンドリア DNA についてはPCR に使用したプライマー（LCO1490 と
HCO 2198）を用いてシーケンス反応を行った。その後, 反 応液を宇都宮大学ゲノミクス教育研究センターに提出し, DNA オートシーケンサーABI3500 Genetic Analyzer (Applied Boisystems）による解析を委託した。取得した DNA の塩基 配列は目視およびBIOEDIT7.2.5.0（Hall 1999）を用いて整 列（アライメント）した。各個体間の塩基配列のマルチプ ルアライメントは CLUSTAL W（Thompson et al. 1994）を 用い, その後手動で調整した。28S リボソーム DNA につい ては, DNA Data Bank of Japan（DDBJ）に登録されている Hamaguchi and Goto (2010) のカシナガの 28S リボソーム DNA 塩基配列（accession no.: AB478192）を参照してアラ イメントした。

さらに, カシナガの地理的遺伝構造を調べるため, Hamaguchi et al. (2011) がカシナガで開発した 6 遺伝子座 の核 DNA の SSR マーカーを用いた解析を行った。各個体 群 10〜32 個体を解析に供した（表-1）。PCRは, Type-it Microsatellite Kit（Qiagen）を用いて, 反応液の全量が $4 \mu \mathrm{L}$ になるように試薬調整した。内訳は $10 \mathrm{ng}$ の鋳型 DNA, 1 $\times$ Type-it Multiplex PCR Master Mix, $0.2 \mu \mathrm{M}$ の Forward お よび Reverse の各プライマーである。なお，各プライマーの うち Forward プライマーを蛍光色素（NED, FAM, VICま たはPET）で標識した。PCR 増幅は Type-it Microsatellite Kit に従い反応条件を設定した。予熱を $95^{\circ} \mathrm{C} て ゙ 5$ 分間行っ た後， 1 サイクルにつき熱変性を $95^{\circ} \mathrm{C}$ で 30 秒，アニーリン グを $60^{\circ} \mathrm{C}$ で 1 分 30 秒，伸長を $72^{\circ} \mathrm{C}$ で 30 秒とし，これを 28 サイクル行った。サイクル終了後の伸長は $60^{\circ} \mathrm{C}$ で 30 分 とした。PCR 増幅には GeneAmp PCR system 2720 を用いた。 その後, 反応液を宇都宮大学ゲノミクス教育センターに提 出し, DNA オートシーケンサーABI3500 Genetic Analyzer に よるフラグメント解析を委託した。解析により得られたデー 夕は, GeneMapper ver.4.1 (Applied Biosystems) を用いて増 幅断片のサイズから，各サンプルの遺伝子型を決定した。

\section{3. データ解析}

ミトコンドリア DNA のハプロタイプ間の系統関係は, Network ver.5.0（Bandelt et al. 1999）の Median-joining 法で 評価した。外群としてルイスナガキクイムシを用いた。ま た, Arlequin ver.3.5（Excoffier and Lischer 2010）を用いて 遺伝子多様度および塩基多様度を算出した。また, 個体群 内と個体群間の遺伝的分化の程度を分子分散分析 (Analysis of Molecular Variance ; AMOVA) (Excoffier et al. 1992) に よって評価した。

核 SSR マーカーで得られたデータについては, GenAlEx ver.6.4（Peakall and Smouse 2006）を用いて各遺伝子座で 観察された対立遺伝子数 $\left(N_{\mathrm{A}}\right)$, ヘテロ接合度の観察值 $\left(H_{\mathrm{O}}\right)$, ヘテロ接合度の期待值 $\left(H_{\mathrm{E}}\right)$, 近交係数 $\left(F_{\mathrm{IS}}\right)$, 個体群間の 分化の指標值の $F_{\mathrm{ST}}, G_{\mathrm{ST}}$ および $G_{\mathrm{ST}}$ （Hedrick 2005）を算 出した。また, GenAlExを用いて, 各遺伝子座の $F_{\text {IS }}$, $F_{\mathrm{ST}}, G_{\mathrm{ST}}$ および $G_{\mathrm{ST}}$ の 0 からの逸脱の有意性を検定した。 さらに, CERVUS ver.3.0.7 (Kalinowsli et al. 2007) を用いて, ヌル対立遺伝子の推定確率 $[F($ Null $)]$ を算出した。

各個体群における遺伝的多様性を評価するため, FSTAT ver.2.9.3.2（Goudet 2001）を用いて，ヘテロ接合度の期待值 
$\left(H_{\mathrm{E}}\right)$ およびアレリックリッチネス $(A r)$ を算出・比較した。 なお， アレリックリッチ采スは最小個体数（岐阜個体群の $N=10$ ）に基づいた值で示した。各個体群におけるこれらの 值の違いは, Steel-Dwass の多重比較検定を用いて評価した。

カシナガの地理的遺伝構造を明らかにするため, GenAlEx を用いた主座標分析 (Principal Coordinate Analysis) および STRUCTURE ver.2.3.4 (Pritchard et al. 2000) を用いた STRUCTURE 解析を行った。STRUCTURE 解析上の設定は, 各供試個体の採集地情報を事前確率として考虑した LOCPRIOR モデル (Hubisz et al. 2009), 混合 (admixture) モデルおよび F モデル (Allele frequency correlated model ; Falush et al. 2003)を用い, burn-in period 20,000 回, MCMC のシミュレーションの繰り返し数を 10,000 回とした。また, 1 から 7 までの各クラス夕ー数 $(K)$ について 10 回の反復計算 を行った。最適クラスター数 $K$ は, STRUCTURE HARVES TER（Earl and vonHoldt 2012）を用いて, Evanno et al. (2005) の $\Delta K$ を指標とする方法と, $K$ に対するデー夕の対数尤度 $P$ $(X \mid K)$ の変化を調へ，対数尤度の上昇変化が緩やかになりか つ主要な遺伝構造を捉える最小の $K$ を探查する方法 (Pritchard et al. 2010) の二つで評価した。さらに，最適クラ スター数において, 10 回の計算結果をCLUMPP ver.1.1.2 (Jakobsson and Rosenberg 2007) お よ び Distruct ver.1.1 （Rosenberg 2004）を用いて一つに統合した。なお，CLUMPP において各 $K$ の 10 回の各ラン間の類似性を示す SSC 值が出 力されるが, 最適クラスター数のこの值が 0.9 以上（例えば Wang et al. 2007) であるか確認した。さらに，近年の急激な 個体群サイズの縮小（ボトルネック）の有無を Bottleneck ver 1.2.02（Cornuet and Luikart 1996; Piry et al. 1999）を用いて調 べた。ボトルネックを受けた個体群は，稀なアレルが急速に 減少する。一方で，へテロ接合度はこの影響をほとんど受け ない。そのため, ボトルネックを受けた個体群では, アレル数 を基に求められる突然変異と遺伝的浮動の平衡状態にあると きのへテロ接合度 $\left(H_{\mathrm{eq}}\right)$ に対して, 実際のへテロ接合度 $\left(H_{\mathrm{e}}\right)$ が大きくなる（へテロ接合度の過剩, $H_{\mathrm{e}}>H_{\mathrm{eq}}$; Cornuet and Luikart 1996 ; Luikart and Cornuet 1998)。これを無限対立遺 伝子モデル（IAM）と，IAM とステップワイズ突然変異モデ ル（SMM）の中間の二相モデル（TPM：IAM が 30\%；SMM が 70\%)の二つのモデルにおいて, Wilcoxon sign-rank test で 片側検定した。ただし，解析個体数の少ない岐阜個体群 $(N$ =10）は解析から除いた。また，各個体群間の遺伝的分化に ついて, Arlequinを用いてペアワイズ $F_{\mathrm{ST}}$ で評価した。

\section{III. 結果}

\section{1. $28 \mathrm{~S}$ リボソーム DNA およびミトコンドリア DNA の系統}

PCR 増幅が成功しなかった岐阜個体群を除く 6 県 52 個

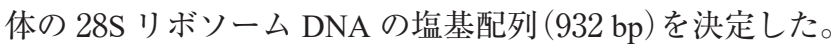
その結果, 二つの遺伝子型が検出された（表-2）。51 個体 は Hamaguchi and Goto (2010) の Type 1 であった。残りの 1 個体は 2 座位がへテロ型である点で, Type 1 と異なる遺 伝子型であり, 本研究では, Type $1 \mathrm{~b}$ と名づけた（表- 2 , JSTAGE 電子付録付表-1)。28S リボソーム DNA の塩基配 列は, DNA Data Bank of Japan（DDBJ）にアクセッション・

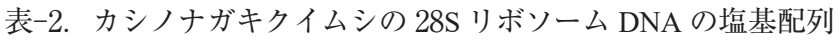
（932 bp）の塩基置換を基に決定した遺伝子型

28S ribosomal DNA genotypes determined based on the substitutions of the sequences (932 bp) of Platypus quercivorus.

\begin{tabular}{|c|c|c|c|}
\hline \multirow{2}{*}{ Genotype } & \multicolumn{2}{|c|}{ Position } & $N$ \\
\hline & 211 & 787 & \\
\hline Type $1^{\#}$ & $\mathrm{C}$ & G & 51 \\
\hline Type $1 b^{\dagger}$ & Y & $\mathrm{R}$ & 1 \\
\hline
\end{tabular}

$N$, number of rDNA genotypes observed; $\mathrm{Y}=\mathrm{C} / \mathrm{T} ; \mathrm{R}=\mathrm{G} / \mathrm{A} ;{ }^{\#}$ Genotype name used in the study by Hamaguchi and Goto (2010; accession no.: AB478192); †newly defined in this study.

\section{ナンバーLC375252-LC375253 で登録した。}

全 7 県の 92 個体についてミトコンドリアDNAの COI 部分領域の塩基配列（658 bp）を決定した。その結果， 25 の塩基置換サイトで識別される 20 のハプロタイプが検出 された（表-3, JSTAGE 電子付録付表-1)。得られたミトコ ンドリア DNA の塩基配列は, DDBJにアクセッション・ナ ンバーLC375254-LC375275 で登録した。ハプロタイプ頻度 （JSTAGE 電子付録付表-1）をみると, ハプロタイプ M1 の 頻度が最も高く全体の $37 \%$ を占めた。ハプロタイプネット ワークをみると, 最も出現頻度の高い $\mathrm{M} 1$ から一斉放散し たハプロタイプが目立ち, 同一の系統ないし近い系統が地 域ごとにまとまることはなかった (図-1)。AMOVA の結果, 有意ではあるものの個体群間の遺伝的分化は小さかった $\left(F_{\mathrm{ST}}=0.088, p<0.001\right)$ このようにミトコンドリア DNA には，群馬のカシナガが移入か在来かを検証する上で必要 な明瞭な地理的遺伝構造はみられないことがわかった。

ミトコンドリアDNA の遺伝子多様度扔よび塩基多様度 は, 解析個体数が少なかった岐皁個体群 $(N=2)$ を除くと, それぞれ $0.728 〜 0.883$ と 0.00270 ～ 0.00434 であった（表4)。これらと比較して, 群馬個体群の值は 0.792 および 0.00350 と中庸であり, 他の個体群と比較して遺伝的多様 性が低いとはいえなかった。

\section{2. 核 DNA の SSR データ解析}

遺伝解析に使用した全 7 県の 145 個体において検出され た 6 遺伝子座の核 SSR マーカーの特性を表-5 に示した。

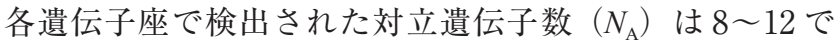
あり, 各遺伝子座のへテロ接合度の観察值 $\left(H_{\mathrm{O}}\right)$ は 0.463 0.778, 各遺伝子座のへテロ接合度の期待值 $\left(H_{\mathrm{E}}\right)$ は 0.487

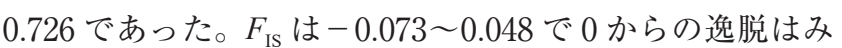
られなかった $(P>0.05) 。 F_{\mathrm{ST}}$ は 0.030 0.057, $G_{\mathrm{ST}}$ は 0.006〜 0.035 および $G_{\mathrm{ST}}^{\prime} 0.020 \sim 0.156$ で，0 からの逸脱は有意で あった。ヌル対立遺伝子の推定確率 $[F$ (Null) $]$ は-0.002 0.057 と小さく, ヌル対立遺伝子は無視できると考えられ た。各個体群におけるへテロ接合度の期待值 $\left(H_{\mathrm{E}}\right)$, アレ リックリッチネス $\left(A r_{[10]}\right)$ はそれぞれ $0.653 \sim 0.701$ およ び 4.167〜 5.377であり, 多重比較検定の結果, いずれの值 においても各個体群間に有意な差はみられなかった $(P>$ 0.05)。主座標分析の結果, 北東グループ（群馬, 新潟, 山形および福島の個体群) と南西グループ (長野, 静岡お よび岐阜の個体群）の二つの地域群に明確に区別された 
表-3. カシノナガキクイムシのミトコンドリア DNA の COI 部分領域の塩基配列（658 bp）の塩基置換を基に決定したハプロタイプ Mitochondrial DNA haplotypes determined based on the substitutions of the partial COI sequences (658 bp) of Platypus quercivorus.

\begin{tabular}{|c|c|c|c|c|c|c|c|c|c|c|c|c|c|c|c|c|c|c|c|c|c|c|c|c|c|c|}
\hline \multirow{2}{*}{ Haplotype } & \multicolumn{25}{|c|}{ Position } & \multirow{2}{*}{$N$} \\
\hline & 79 & 184 & 205 & 262 & 274 & 304 & 325 & 328 & 346 & 370 & 376 & 406 & 412 & 415 & 433 & 466 & 472 & 487 & 505 & 508 & 538 & 548 & 553 & 580 & 637 & \\
\hline M1 & $\mathrm{T}$ & $\mathrm{T}$ & $\mathrm{C}$ & A & A & G & $\mathrm{T}$ & A & A & $\mathrm{C}$ & $\mathrm{T}$ & $\mathrm{T}$ & A & G & G & G & C & A & C & $\mathrm{C}$ & G & $\mathrm{T}$ & A & $\mathrm{C}$ & C & 34 \\
\hline M2 & . & $\mathrm{C}$ & . & & . & & . & . & . & . & . & & . & & . & A & . & . & . & & . & & . & . & . & 12 \\
\hline M3 & . & $\mathrm{C}$ & . & . & . & . & . & . & . & . & . & . & G & . & . & A & . & . & . & . & . & . & . & . & . & 10 \\
\hline M4 & . & . & $\mathrm{T}$ & . & . & . & . & . & . & . & . & $\mathrm{C}$ & . & . & $\cdot$ & . & . & . & $\mathrm{T}$ & . & . & $\mathrm{C}$ & . & . & . & 5 \\
\hline M5 & $\cdot$ &. & $\cdot$ & . & $\cdot$ & A & . & . & $\mathrm{C}$ & . & . & $\cdot$ & $\cdot$ & . & $\cdot$ & A & . & . & . & . & $\cdot$ & $\cdot$ & . & . & . & 4 \\
\hline M6 & . & & . & & $\mathrm{C}$ & & $\cdot$ & & . & & $\mathrm{C}$ & &. & & $\cdot$ & & . & & . & & . & & . & & . & 4 \\
\hline M7 & . & . & . & . & . & . & . & G & . & . & . & . & . & . & $\cdot$ & . & . & . & . & . & . & . & . & . & . & 3 \\
\hline M8 & . & . & . & . & . & . & . & . & . & . & . & . & . & . & . & . & $\mathrm{T}$ & . & $\cdot$ & . & A & . & . & $\cdot$ & . & 3 \\
\hline M9 & . &. & . & G & . &. & $\mathrm{C}$ & . & . & . & . & . & . & . & . & . & . & G & . &. & $\cdot$ & . & . & $\cdot$ & . & 2 \\
\hline M10 & . & & . & & $\cdot$ & & $\cdot$ & & . & & . & & . & & . & & . & & . & & . & & . & $\mathrm{T}$ & . & 2 \\
\hline M11 & . & . & . & . & $\cdot$ & . & . & . & . & . & . & . & . & . & . & . & . & . & $\mathrm{T}$ & . & . & . & . & . & . & 2 \\
\hline M12 & . & $\cdot$ & . & $\cdot$ & . & $\cdot$ & $\cdot$ & . & $\cdot$ & . & . & . & $\cdot$ & . & . & . & . & . & . & $\mathrm{T}$ & . & . & $\cdot$ & . & . & 2 \\
\hline M13 & . & . & . & . & . & . & . & . & . & . & . & $\cdot$ & . & . & . & . & . & . & . & $\cdot$ & . & . & G & . & . & 2 \\
\hline M14 & $\cdot$ & . & . & . & . & . & . & . & . & . & . & . & . & . & . & . & . & . & . & . & . & . & . & . & $\mathrm{T}$ & 1 \\
\hline M15 & . & . & $\mathrm{A}$ & . & $\cdot$ & . & . & . & $\mathrm{T}$ & . & . & . & . & . & $\mathrm{A}$ & . & . & . & . & . & . & . & . & . & $\cdot$ & 1 \\
\hline M16 & . & $\cdot$ & . & . & $\cdot$ & . & . & . & . & . & $\mathrm{C}$ & . &. & . & . & . & . & . &. & . &. & . & . & . & . & 1 \\
\hline M17 & . & . & . & . & . & . & $\cdot$ & . & . & $\mathrm{T}$ & $\cdot$ & $\cdot$ & $\cdot$ & $\cdot$ & . & $\cdot$ & $\cdot$ & . & . & . & . & . & $\cdot$ & $\cdot$ & . & 1 \\
\hline M18 & $\cdot$ & $\cdot$ & $\cdot$ & $\cdot$ & $\cdot$ & $\cdot$ & $\cdot$ & $\cdot$ & $\cdot$ & $\cdot$ &. & $\cdot$ & $\mathrm{C}$ & $\cdot$ & $\cdot$ & $\cdot$ & $\cdot$ & $\cdot$ & . & . & $\cdot$ & . & . & $\cdot$ & . & 1 \\
\hline M19 & $\cdot$ & $\cdot$ & $\cdot$ & $\cdot$ & $\cdot$ & $\cdot$ & $\cdot$ & $\cdot$ & $\cdot$ & $\cdot$ & $\cdot$ & $\cdot$ & $\cdot$ & A & $\cdot$ & . & . & . & $\cdot$ & $\cdot$ & . & $\cdot$ & . & . & $\cdot$ & 1 \\
\hline M20 & A & & . & & . & & . & & . & & . & & . & & . & & . & & . & & . & & . & & . & 1 \\
\hline
\end{tabular}

Dot (.) indicates the same base to that of $\mathrm{Ml}$ at the same position; $N$, number of mtDNA haplotypes observed.

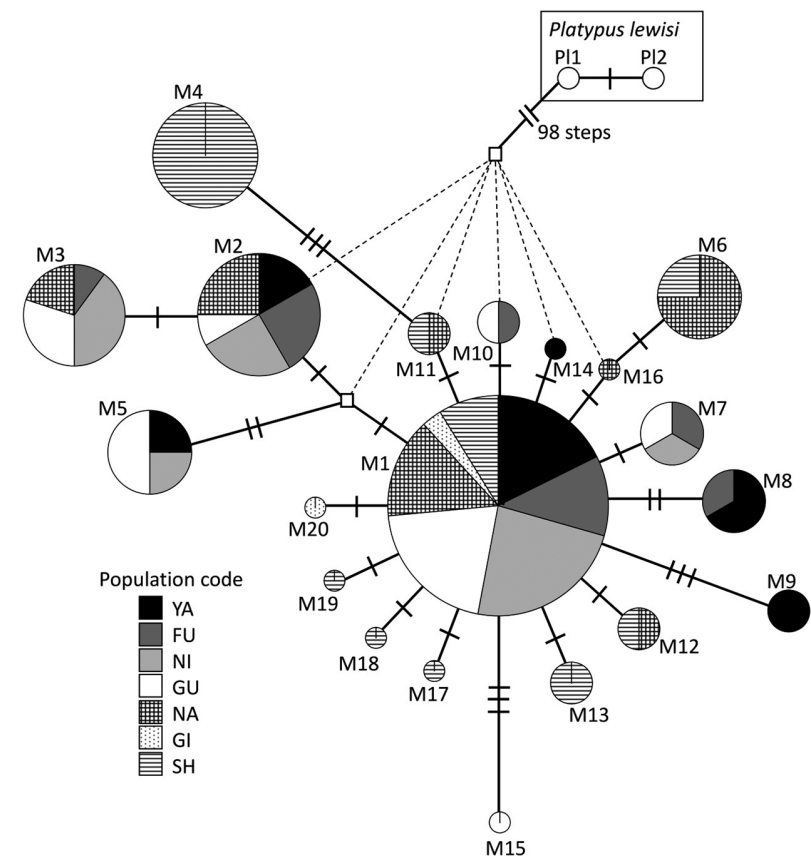

図-1. カシノナガキクイムシのミトコンドリア DNA の COI 部分 領域のハプロタイプネットワーク

Median-joining network inferred from partial COI sequences of mitochondrial DNA of Platypus quercivorus.

Open squares indicate missing haplotypes; dot lines indicate an unresolved network, including 41 missing haplotypes; the circle size of each haplotype is approximately proportional to the frequency of the haplotype; bar on each node indicates substitution site; population codes correspond to those shown in Table 1.
表-4. カシノナガキクイムシ個体群のミトコンドリアDNAの COI 部分領域および 6 遺伝子座の核マイクロサテライトの 遺伝的多様性

Genetic diversity of Platypus quercivorus populations assessed using partial COI sequences of mitochondrial DNA and six nuclear microsatellite loci.

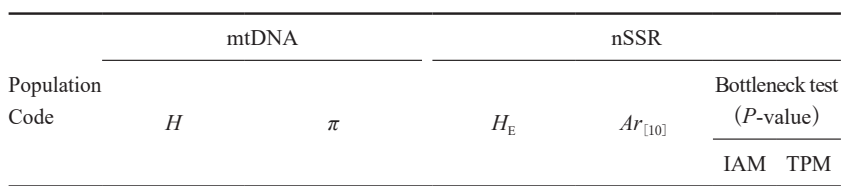

$\begin{array}{lllllll}\text { YA } & 0.802(0.091) & 0.00361(0.00234) & 0.660(0.126) & 4.949(0.865) & 0.344 & 0.922\end{array}$

\begin{tabular}{llllllll}
\hline FU & $0.836(0.089)$ & $0.00293(0.00203)$ & $0.680(0.112)$ & $5.296(0.657)$ & 0.422 & 0.922
\end{tabular}

\begin{tabular}{llllllll}
\hline NI & $0.728(0.083)$ & $0.00270(0.00184)$ & $0.701(0.129)$ & $5.377(0.784)$ & 0.281 & 0.578
\end{tabular}

\begin{tabular}{llllllll}
\hline GU & $0.792(0.089)$ & $0.00350(0.00226)$ & $0.697(0.139)$ & $5.324(1.068)$ & 0.219 & 0.422
\end{tabular}

\begin{tabular}{lllllll}
\hline $\mathrm{NA}$ & $0.858(0.057)$ & $0.00323(0.00212)$ & $0.687(0.077)$ & $5.289(0.852)$ & 0.578 & 0.945
\end{tabular}

\begin{tabular}{lllll}
\hline GI & $1.000(0.500)$ & $0.00152(0.00215)$ & $0.653(0.122)$ & $4.167(1.329)$
\end{tabular}

\begin{tabular}{lllllll}
\hline SH & $0.883(0.061)$ & $0.00434(0.00270)$ & $0.683(0.075)$ & $4.424(0.784)$ & 0.039 & 0.219
\end{tabular}

Population codes correspond to those shown in Table 1; $H$, haplotypic diversity; $\pi$, nucleotide diversity; $H_{\mathrm{E}}$, expected heterozygosity, $A r_{[10]}$, allelic richness based on the minimum sample size of 10 diploid individuals; -, not tested because of small sample size.

(図-2)。また, STRUCTURE 解析の結果, $\Delta K$ および対数 尤度 $P(X \mid K)$ は $K=2$ のときにいずれも最大となった (JSTAGE 電子付録付図-1)。10 回の各ラン間の類似度を示 す SSC 值は, $K=2$ で 0.958 (個体デー夕) および 0.969 (個 体群デー夕）であったが， $K=3$ では，いずれのデー夕も SSC 值は 0.80 以下であった。したがって, 本研究では $K$ 
$=2$ を最適クラスターと判断した。 $K=2$ のとき, 糸魚川 静岡構造線（図-3 の灰色ライン）を境に，クラスターIは その北東側に位置する山形, 福島, 新潟および群馬の個体 群で優占し，クラスターII は構造線上およびその南西側の 長野, 静岡および岐阜の個体群で優占していた（図-3）。

近年のボトルネックの有無を調べた結果，静岡個体群の IAM $(P=0.039)$ 以外は，いずれの個体群・モデルにおい てもボトルネックは検出されなかった $(P>0.05$; 表-4)。

各個体群間のペアワイズ $F_{\mathrm{ST}}$ 值は, 福島と長野個体群の ペアを除いて，糸魚川静岡構造線をまたぐ個体群ぺアにお いてすべて有意であった（表-6）。糸魚川静岡構造線の北 東側に位置する四つの個体群間では, 山形と新潟個体群間 を除いて有意な遺伝的分化はみられなかった（表-6）。群 馬と新潟個体群間においても遺伝的分化はみられなかった (ペアワイズ $F_{\mathrm{ST}}=0.00002 ， P>0.05$; 表-6)。このように, カシナガにみられた遺伝的分化は主として糸魚川静岡構造 線をまたぐ個体群間で生じていた。

\section{IV. 考察}

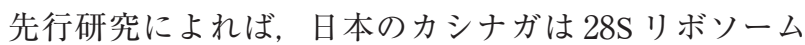
DNA の遺伝構造に基づいて日本海型と太平洋型に分かれ (Hamaguchi and Goto 2010)，日本海型のカシナガは，さ らに，核のSSR マーカーを用いた遺伝解析により，糸魚

表-5. 使用した 6 遺伝子座の核マイクロサテライトマーカーの特徵 Characteristics of six nuclear microsatellite loci used for genetic analyses.

\begin{tabular}{lcccrccccc}
\hline Locus & $N_{\mathrm{A}}$ & $H_{\mathrm{O}}$ & $H_{\mathrm{E}}$ & \multicolumn{1}{c}{$F_{I S}$} & \multicolumn{1}{c}{$F_{\text {ST }}$} & $G_{\text {ST }}$ & $G_{\text {ST }}^{\prime}$ & $F_{\text {(Null) }}$ & Dye \\
\hline Pq2988 & 10 & 0.463 & 0.487 & 0.048 & $0.056^{* *}$ & $0.031^{* *}$ & $0.068^{* *}$ & 0.057 & FAM \\
Pq3003 & 10 & 0.654 & 0.652 & -0.003 & 0.030 & 0.006 & 0.020 & 0.026 & FAM \\
Pq3313 & 8 & 0.711 & 0.716 & 0.007 & $0.044^{*}$ & $0.020^{*}$ & $0.086^{*}$ & 0.042 & VIC \\
Pq3422 & 9 & 0.702 & 0.703 & 0.001 & 0.035 & 0.011 & 0.043 & 0.023 & NED \\
Pq3423 & 12 & 0.727 & 0.685 & -0.062 & $0.056^{* *}$ & $0.033^{* *}$ & $0.126^{* *}$ & 0.001 & NED \\
Pq3469 & 9 & 0.778 & 0.726 & -0.073 & $0.057 * *$ & $0.035^{* *}$ & $0.156^{* *}$ & -0.002 & PET \\
Overall & & & & -0.017 & $0.046^{* * *}$ & $0.023^{* *}$ & $0.079 * *$ & &
\end{tabular}

$N_{\mathrm{A}}$, number of alleles per locus; $H_{O}$, observed heterozygosity; $H_{\mathrm{E}}$, expected heterozygosity; $F_{\mathrm{IS}}$, inbreeding coefficient within individuals; $F_{\mathrm{ST}}$ and $G_{\mathrm{ST}}$, measures of genetic differentiation among populations; $G_{\mathrm{ST}}^{\prime}$, Hedrick's standardized measure of genetic differentiation; $* P<0.05 ; * * P<0.01$; significance was tested using 999 permutations; $F_{\text {(Null) }}$, null allele frequencies; Dye, fluorescence dye.

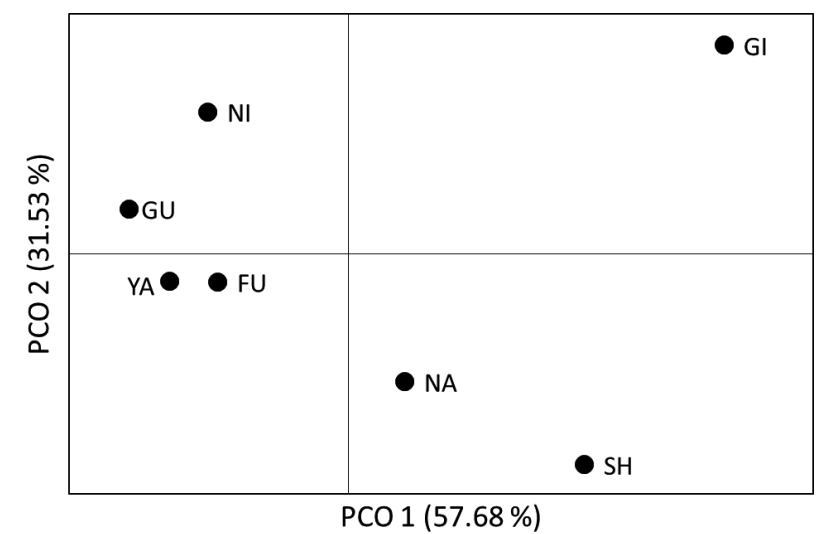

困-2. カシノナガキクイムシの 6 遺伝子座の核 DNA のマイクロ サテライトマーカーを用いた主座標分析の結果

Result of principal coordinate analysis for Platypus quercivorus using six nuclear microsatellite loci.

Population codes correspond to those shown in Table 1 .
川静岡構造線を境に北東日本タイプと南西日本タイプに分 かれる（Shoda-Kagaya et al. 2010）。28S リボソーム DNA の解析の結果, 本研究で用いた解析個体群は群馬県を含め ていずれも日本海型であった。さらに核 SSR の遺伝構造 解析の結果, 群馬個体群は, 新潟, 福島抒よび山形の個体 群とともに糸魚川静岡構造線の北東に拡がるタイプに属す ることが明らかとなった（図-3）。新潟扔よび山形が北東 タイプに属することは, Shoda-Kagaya et al.（2010）の結 果と一致していた。これらのことから二つ目の仮説である 群馬県へ遠い系統である太平洋型や日本海型の南西タイプ のカシナガが移入したのではないことが示唆された。

前述したように, 一般的に分布拡大などで生じた少数個 体を起源とする個体群の遺伝的多様性は創始者効果によっ て減少がみられる。また，ミトコンドリア DNA は半数体 であるため, 二倍体の核 DNA マーカーよりも遺伝的浮動 の影響を強く受けやすく（Sinclair et al. 1999），ミトコン ドリア DNA は核 DNA に比べて 4 倍の速度で遺伝的多様

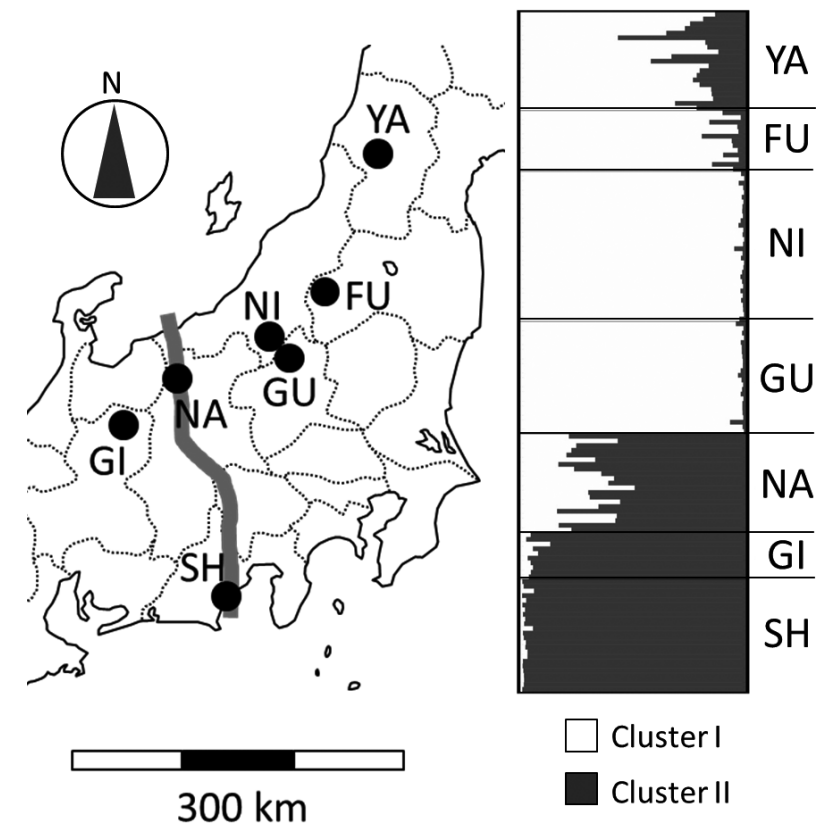

図-3. STRUCTURE 解析によって推定したクラスター数 $(K)=2$ におけるカシノナガキクイムシの遺伝構造

Genetic structure of Platypus quercivorus obtained using STRUCTURE analysis.

Each individual is represented by a thin horizontal line at the number of cluster $(K)=2$. The thick gray line indicates the Itoigawa-Shizuoka Tectonic Line; population codes correspond to those shown in Table 1.

表-6. 核 SSR の 6 遺伝子座を用いて推定した各個体群間の遺伝 的分化 (ペアワイズ $F_{\mathrm{ST}}$ )

Population Pairwise $F_{\mathrm{ST}}$ estimated using six nuclear microsatellite loci.

\begin{tabular}{|c|c|c|c|c|c|c|c|}
\hline & YA & $\mathrm{FU}$ & NI & GU & NA & GI & SH \\
\hline YA & - & & & & & & \\
\hline $\mathrm{FU}$ & 0.00509 & - & & & & & \\
\hline NI & $0.01982^{*}$ & -0.00037 & - & & & & \\
\hline GU & 0.01154 & -0.00519 & 0.00002 & - & & & \\
\hline NA & $0.02137^{*}$ & -0.00615 & $0.01995^{* *}$ & $0.02012^{* *}$ & - & & \\
\hline GI & $0.06542 * * *$ & $0.04973 * * *$ & $0.04127 * * *$ & $0.06024 * *$ & $0.03807 *$ & - & \\
\hline SH & $0.04361^{* * * *}$ & $0.02744 * * *$ & $0.05037 * * *$ & $0.04489 * * *$ & 0.00307 & $0.03888 * * *$ & - \\
\hline
\end{tabular}

Population codes correspond to those shown in Table $1 ; *<0.05 ; * *<0.01 ; * * * 0.001$; the values in the box indicate those obtained between populations located on both sides of the Itoigawa-Shizuoka Tectonic Line. 
性が減少するといわれている（井鷺・陶山 2013）。したがっ て，群馬県のカシナガが近隣県からの近年の自然あるいは 人為的な移入個体群であるならばミトコンドリアDNAの 遺伝的多様性は低下すると予想される。しかし, 本研究の 結果，群馬個体群の核 SSR およびミトコンドリアDNAの 遺伝的多様性は，他の個体群と比較して低くなく（表-4,

5), Shoda-Kagaya et al.（2010）が核 SSR マーカーを用い て調べた東北から北陸までのカシナガの遺伝的多様性の值 と同程度であった。また，近年のボトルネックは検出され なかった。このことから，一つ目の仮説である群馬県のカ シナガが近隣県からの近年の自然移入あるいは人為的に移 入した個体群でもないことが示唆される。

したがって，三つ目の在来個体群由来の仮説が支持され る。ただ，本研究で群馬と新潟の個体群間の遺伝的分化が みられなかったことから，より長い時間（世代）スケール でみると，群馬個体群は在来由来であっても，両個体群間 の分化後の時間は比較的浅いか，何らかの遺伝的な交流か 保たれていることが示唆される。一方, 本研究の結果, 静 岡個体群のみで有意なボトルネックが検出された（表-4）。 静岡県内では県西部から東に向かって徐々にナラ枯れが拡 大したこと（静岡県 2016）を考慮すると，静岡個体群に ついては，近隣から近年移入した可能性も否定できない。

以上から，群馬県のナラ枯れを起こしたカシナガは在来 であることが示唆された。ナラ枯れ被害が発生するために は一定数のカシナガ成虫数が必要とされることから（江崎 ら 2009)，2010年に群馬県でナラ枯れが初発する以前か らおそらく在来のカシナガが生息していたが，個体数密度 が低かったために被害が起きなかったものと考えられる。 群馬県において個体群密度が高まった要因についてははっ きりしないが，水上が多雪地域であることを考慮すると， 要因の一つとして気象要因が考えられる。冬季の材内にお けるカシナガ幼虫の生存率は積雪期間が長くなると低下す るとされる（松浦・中島 2011）。また，カシナガの穿入孔 は樹幹下部ほど多い（小林・野崎 2003）。気象庁みなかみ 観測所の 3 月の最深積雪（1990～2018 年）は平均 $110 \mathrm{~cm}$ であるが，2007 年， 2009 年および 2010 年は $80 \mathrm{~cm}$ 以下の 年が続いた（気象庁 2018）。このためカシナガ幼虫の生存 率が下がらず, 成虫の個体群密度が高く維持されたのかも しれない。

これまで発生したナラ枯れ被害の中には，例えば，静岡 県の伊豆地方（加藤 2014 ; 澤田ら 2014 ; 静岡県 2016), 神奈川県箱根町および三浦市（神奈川県 2017），千葉県鴨 川市（千葉県 2017）のように前年の被害地から $10 \mathrm{~km}$ 以 上離れた場所や，周辺で被害のない場所で飛び地的に発生 した被害も多い。伊豆地域では，隣接地である富士地域で カシナガが確認されていないことから伊豆地域の個体群は 独立した個体群である可能性が高いとされた（加藤 2014）。本研究より, 群馬県のナラ枯れが在来のカシナガ によって起きたことが示唆されたことを考慮すると，これ ら無被害地で突然発生したナラ枯れも在来個体群のカシナ ガにより引き起こされた可能性も考慮すべきであろう。従 来, ナラ枯れ被害発生予測は, 主として被害地からのカシ
ナガの移動による拡大を前提として行われてきた。しかし， 本研究の結果に基づくと, Shoda-Kagaya et al. (2010) が 指摘するように, 近隣での被害の有無や前年の被害地との 距離に関わらず，未被害のナラ類が分布する地域における カシナガの生息の有無の調査が, 被害予防の観点から重要 と考えられる。なお, カシナガが在来であっても, ナラ菌 が何らかのかたちで近年移入した，あるいは病原性が高 まったことでナラ枯れ被害が発生した可能性も考えられ る。しかし, 本研究では, ナラ菌の由来まで調べることが できなかった。この点については今後の課題である。

謝 辞

本研究の試料採集にあたって, 群馬県林業試験場の伊藤英敏氏, 山形県森林研究研修センターの齊藤正一氏, 小谷村キハダ生産組合 の山口真保呂氏, 岐阜県森林研究所の大橋章博氏, 静岡県農林技術 研究所森林 - 林業センターの加藤徹氏, 福島県只見町役場の中野陽 介氏, 只見町ブナセンター, 宇都宮大学農学部森林科学科森林生態学・ 育林学研究室の諸氏のご協力をいただいた。森林総合研究所森林昆 虫研究領域の北島博氏より, 試料採集地の情報を提供していただい た。宇都宮大学バイオサイエンス教育研究センターの相蘇春菜博士 にはシーケンス解析とフラグメント解析をしていただいた。本原稿 の査読者の方々より有益なコメントをいただいた。以上の方々に心 より御礼申し上げます。

\section{引用文献}

在原登志雄・松崎 明 · 斎藤直彦 ·石井洋二 (2008) ナラ類集団枯損 に関する防除技術の開発. 福島県林業研究センター報告 41: 47116

浅野浩之 (2011) 群馬県でナラ枯れ被害が発生. 群馬県林業試験場 http://www.pref.gunma.jp/07/p13700231.html (2018.5.9 閲覧)

Bandelt HJ, Forster P, Rohl A (1999) Median-joining networks for inferring intraspecific phylogenies. Mol Biol Evol 16: 37-48

Bernays EA, Chapman RF (1994) Host-plant selection by phytophagous insects. Springer

千葉県（2017）ナラ枯れ（カシノナガキクイムシ）の情報提供に御協 力願います. 千葉県農林水産部森林課 https://www.pref.chiba.lg.jp/ shinrin/documents/chirasi.pdf (2018.5.4 閲覧)

Cornuet JM, Luikart G (1996) Description and power analysis of two tests for detecting recent population bottlenecks from allele frequency data. Genetics 144: 2001-2014

Earl DA, vonHoldt BM (2012) STURUCTURE HARVESTER: a website and program for visualizing STRUCTURE output and implementing the Evanno method. Conservation Genet Resour 4: 359-361

江崎功二郎 - 加藤賢隆・鎌田直人（2009）樹幹表面におけるカシノナ ガキクイムシの初期穿入分布. 日林誌 91: 208-211

Evanno G, Regnaut S, Goudet J (2005) Detecting the number of clusters of individuals using the software STRUCTURE: a simulation study. Mol Ecol 14: 2611-2620

Excoffier L, Lischer HE (2010) Arlequin suite ver 3.5 : a new series of programs to perform population genetics analyses under Linux and Windows. Mol Ecol Resour 10: 564-567

Excoffier L, Smouse PE, Quattro JM (1992) Analysis of molecular variance inferred from metric distances among DNA haplotyoes: Application to human mitochondrial DNA restriction data. Genetics 131: 479-491

Falush D, Stephens M, Pritchard JK (2003) Inference of population structure using multilocus genotype data: linked loci and correlated allele frequencies. Genetics 164: 1567-1587

Frankham R, Ballou JD, Briscoe DA (2002) Introduction to Conservation Genetics. Cambridge University Press [Frankham R, Ballou JD, Briscoe DA 西田睦（訳）（2007）保全遺伝学入門。文一総合出版]

Goudet J (2001) FSTAT, a program to estimate and test gene diversities and fixation indices (version2.9.3) http://www2.unil.ch/popgen/softwares/ fstat.htm.

Hall TA (1999) BioEdit: a user-friendly biological sequence alignment editor and analysis program for Windows 95 / 98 /NT. Nuleic Acids Symp Ser 41: 95-98

Hamaguchi K, Goto H (2010) Genetic variation among Japanese 
populations of Platypus quercivorus (Coleoptera: Platypodidae), an insect vector of Japanese oak wilt disease, based on partial sequence of nuclear 28S rDNA. Appl Entomol Zool 45: 319-328

Hamaguchi K, Kato K, Esaki K, Kamata N (2011) Isolation and characterization of 10 new microsatellite loci in the ambrosia beetle Platypus quercivorus. J For Res 16: 518-521

Hebert PDN, Cywinska A, Baall SL, deWaard JR (2003) Biological identification through DNA barcodes. Proc R Soc Lond B Bio Sci 270: 313-321

Hedrick PW (2005) A standardized genetic differentiation measure. Evolution 25: 1633-1638

Hubisz MJ, Falush D, Stephens M, Pritchard JK (2009) Inferring weak population structure with the assistance of sample group information. Mol Ecol Resour 9: 1322-1332

伊藤進一郎・山田利博 (1998) ナラ類集団枯損被害の分布と拡大. 日 林誌 80: 229-232

井熟裕司・陶山佳久 (2013) 生態学者が書いた DNA の本 メンデルの法 則から遺伝情報の読み方まで。文一総合出版

Jakobsson M, Rosenberg NA (2007) CLUMPP: a cluster matching and permutation program for dealing with label switching and multimodality in analysis of population structure. Bioinformatics 23: $1801-1806$

Kalinowski ST, Taper ML, Marshall TC (2007) Revising how the computer program CERVUS accommodates genotyping error increases success in paternity assignment. Mol Ecol 16: 1099-1106

神奈川県 (2017) ナラ枯れについて. http://www.pref.kanagawa.jp/cnt/ f537128/ (2018.5.4 閲覧)

加藤 徹 (2014) 静岡県におけるカシノナガキクイムシの分布拡大. 静岡県農林技術研究所研究報告 (森林・林業編) (7): 63-69

Kim CG, Zhou HZ, Imura Y, Tominaga O, Su ZH, Osawa S (2000) Pattern of morphological diversification in the Leptocarabus ground beetles (Coleoptera: Carabidae) as deduces from mitochondrial ND5 gene and nuclear 28S rDNA sequences. Mol Biol Evol 17: 137-145

気象庁 (2018) みなかみ, 年ごとの值, 詳細（雪）。 http://www.data.jma go.jp/obd/stats/etrn/view/annually a.php?prec no $=42$ \&block no $=1019$ \&year $=2017 \&$ month $=\&$ day=\&view=a4 $(2018.5 .8$ 閲覧 $)$

小林正秀・野崎 愛 (2003) ミズナラにおける地上高別のカシノナガ キクイムシの穿入孔数と成虫脱出数. 応用森林研究 12: 143-149

小林正秀・野崎 愛 (2009) ナラ枯れ被害をどう防ぐのか一被害のメ カニズムと防除法一。京都府林業試験場

小林正秀・荻田 実 (2000) ナラ類集団枯損の発生経過とカシノナカ キクイムシの捕獲，森林応用研究 9 (1): 99-103

小林正秀・上田明良 (2001) ナラ類集団枯損発生直後の林分における カシノナガキクイムシの穿入と立木の被害状況（II）一京都府和 知町と京北町における調査結果一. 森林応用研究 $10(2)$ : 79-84

小林正秀・上田明良（2005）カシノナガキクイムシとその共生菌が関 与するブナ科樹木萎调枯死一被害発生要因の解明を目指して一 日林誌 87: 435-450

Luikart G, Cornuet JM (1996) Empirical evaluation of a test for identifying recently bottlenecked populations from allele frequency data. Conserv Biol 12: 228-237

松浦嵩遠・中島春樹 (2011)「ナラ枯れ」Q＆A．富山県農林水産総合 研究センター森林研究所研究レポート 2: 1-16

Milligan RH (1982) Evidence for an aggregating pheromone in Platypus apicalis (Coleoptera: Platypodidae). In Insect Pheromones and Their Application. N. Z. Department of Scientific and Industrial Research Entomology Division Report 2: 37-50
Nobuchi A (1973) The Platypodidae of Japan (Coleoptera). Bull Gov For Exp Sta 256: 1-22

布川耕市（1993）新潟県におけるカシノナガキクイムシの被害とその 分布について．森林防疫 42: 210-213

布川耕市 (2001) 新潟県におけるナラ類集団枯損被害の地域分布およ び標高分布. 新潟県森林研報 43: 33-49

布川耕市 (2007) 新潟県におけるナラ類集団枯損被害の地域分布と拡 大経過. 新潟県森林研報 48: 21-32

Peakall R, Smouse PE (2006) GENALEX 6: genetic analysis in Excel. Population genetic software for teaching and research. Mol Ecol Notes 6: 288-295

Piry S, Luikart G, Cornuet JM (1999) BOTTLENECK: a computer program for detecting recent reductions in the effective population size using allele frequency data. J Hered 90: 502-503

Pritchard JK, Stephens M, Donnelly P (2000) Inference of population structure using multilocus genotype data. Genetics 155: 945-959

Pritchard JK, Wen X, Falush D (2010) Documentation for structure software: Version 2.3. https://web.stanford.edu/group/pritchardlab/ structure_software/release_versions/v2.3.4/structure_doc.pdf (2018 . 6.11 閲覧)

林野庁 (2015) ナラ枯れ被害対策マニュアル改訂版 http://www.rinya. maff.go.jp/j/hogo/higai/pdf/naragaremanyual2.pdf (2018.3.6 閲覧)

林野庁 (2017) 病害虫や動物被害から森林を守る!ナラ枯れ被害 http:// www.rinya.maff.go.jp/j/hogo/higai/naragare.html (2018.3.6 閲覧)

Rosenberg NA (2004) DISTRUCT: a program for the graphical display of population structure. Mol Ecol Notes 4: 137-138

佐藤 明・野堀嘉裕・高橋教夫・斎藤正一 (2004) GIS を用いた山形 県朝日村におけるナラ類集団枯損の地理的特徵解析. 東北森林 学会誌 9: 13-20

澤田晴雄 - 辻 和明 - 辻 良子 - 小林徹行 - 井上広喜 - 鴨田重裕 · 鎌田直人 (2014) 東京大学樹芸研究所青野研究林におけるカシノ ナガキクイムシ穿入木の発生状況. 中部森林研究 62: 55-58

静岡県 (2016) 静岡県ナラ枯れ被害対策ガイド. https://www.pref.shizuoka. jp/sangyou/sa-850/naragaregaido2016.pdf (2018.5.8 閲覧)

Sinclair WT, Morman JD, Ennos RA (1999) The postglacial history of scots pine (Pinus sylvestris L.) in western Europe: evidence from mitochondrial DNA variation. Mol Ecol 8: 83-88

Shoda E, Kubota K, Makihara H (2003) Geographical structuring of mito chondrial DNA in Semanotus japonicus (Coleoptera: Cerambycidae). Appl Entomol Zool 38: 339-345

Shoda-Kagaya E, Saito S, Okada M, Nozaki A, Nunokawa K, Tsuda Y (2010) Genetic structure of the oak wilt vector beetle Platypus quercivorus: inferences toward the process of damaged area expansion. BMC Ecol 10: 21

Thompson JD, Higgins DG, Gibson TJ (1994) The CLUSTAL W: improving the sensitivity of progressive multiple sequence alignment through sequence weighting, position-specific gap penalties and weight matrix choice. Nucleic Acids Res 22: 4673-4680

Wang S, Lewis CM, Jakobsson M, Ramachandran S, Ray N, Bedoya G, Rojas W, Parra MV, Molina JA, Gallo C, Mazzotti G, Poletti G, Hill K, Hurtado AM, Labuda D, Klitz W, Barrantes R, Bortolini MC, Salzano FM, Petzl-Erler ML, Tsuneto LT, Llop E, Rothhammer F, Excoffier L, Feldman MW, Rosenberg NA, Ruiz-Linares A (2007) Genetic variation and population structure in native Americans. PLoS Genet 3: e185.

渡辺昭彦 (2009) 吊り下げ式簡易型屋根付き FIT とその作り方. 甲虫 ニュース 166: 7-9 